\title{
BIOKONVERSI KULIT PISANG RAJA (Musa paradisiaca) DENGAN Rhizopus oligosphorus TERHADAP PERUBAHAN KANDUNGAN ABU, SERAT KASAR DAN LEMAK KASAR
}

\author{
Jandrivo M. Manorek , F. R. Wolayan*, I. M. Untu, H. Liwe \\ Fakultas Peternakan Universitas Sam Ratulangi Manado
}

\begin{abstract}
ABSTRAK
Penelitian ini bertujuan untuk mengetahui pengaruh perlakuan dosis inokulum dan waktu ferementasi pada kulit pisang raja (Musa paradisiaca) terhadap perubahan kandungan abu, serat kasar dan lemak kasar. Penelitian ini dilakukan dengan menggunakan limbah kulit pasang raja (Musa paradisiaca) dengan Rhizopus oligosphorus sebagai inokulum. Rancangan yang digunakan adalah RAL dengan 9 perlakuan dan 3 ulangan. Perlakuan terdiri atas P1 (dosis inokulum $0,2 \%$ dan waktu fermentasi 48 jam), P2 (dosis inokulum $0,4 \%$ dan waktu fermentasi 48 jam), P3 (dosis inokulum 0,6\% dan waktu fermentasi 48 jam), P4 (dosis inokulum $0,2 \%$ dan waktu fermentasi 96 jam), P5 (dosis inokulum 0,4\% dan waktu fermentasi 96 jam), P6 (dosis inokulum $0,6 \%$ dan waktu fermentasi 96 jam), P7 (dosis inokulum 0,2\% dan waktu fermentasi 144 jam), P8 (dosis inokulum $0,4 \%$ dan waktu fermentasi 144 jam), P9 (dosis inokulum 0,6\% dan waktu fermentasi 144 jam), Penelitian ini sudah dilakukan sejak 12 Februari sampai 3 Maret 2017 bertempat di Laboratorium Teknologi Pakan Fakultas Peternakan Universitas Sam Ratulangi Manado. Variabel yang diukur pada penelitian ini adalah perubahan kandungan abu, serat kasar dan lemak kasar. Hasil analisis sidik ragam menunjukkan bahwa kulit pisang raja yang difermentasi dengan Rhizopus oligosporus memberikan pengaruh yang berbeda nyata
\end{abstract}

*Korespondensi (corresponding author): Email :feny_wolayan@unsrat.ac.id
$(\mathrm{P}<0,05)$ terhadap perubahan kandungan abu, serat kasar dan lemak kasar. Perlakuan dengan dosis inokulum $0,4 \%$ dengan waktu fermentasi 96 jam memberikan perubahan peningkatan kandungan abu sebesar 37,36\%, perubahan penurunan kandungan serat kasar sebesar $18,38 \%$ dan perubahan penurunan kandungan lemak kasar sebesar 17,33\%.Berdasarkan hasil dan pembahasan, dapat disimpulkan bahwa biokonversi kulit pisang raja (Musa paradisiaca) dengan Rhizopus oligosporus dapat meningkatkan kandungan abu, menurunkan kandungan serat kasar dan lemak kasar.

Kata Kunci : Kulit pisang raja, Biokonversi, Rhizopus oligosphorus

\section{ABSTRACT}

\section{BIOCONVERSION OF BANANA} PEEL (Musa paradisiaca)WITH Rhizopus oligosphorusTO CHANGE IN ASH CONTENT,CRUDE FIBER AND COARSE FAT. The purpose of this study was to investigate the effect of dose inoculum treatment and fermentation time on banana peel (Musa paradisiaca) to changes in ash content, crude fiber, and crude fat. This research was conducted by using banana peel waste (Musa paradisiaca) with Rhizopus oligosphorus as inoculum. The design used was RAL with 9 treatments and 3 replications. The treatments consisted of P1 (dose of inoculum $0.2 \%$ and 48 hours fermentation 
time), P2 (dose of inoculum $0.4 \%$ and 48 hours fermentation time), P3 (dose of inoculum $0.6 \%$ and 48 hours fermentation time), $\mathrm{P} 4$ (dose of inoculum $0.2 \%$ and 96 hours fermentation time), P5 (dose of inoculum $0.4 \%$ and 96 hours fermentation time), P6 (dose of inoculum $0.6 \%$ and 96 hours fermentation time), P7 (dose of inoculum $0.2 \%$ and 144 hours fermentation time), P8 (dose of inoculum $0.4 \%$ and 144 hours fermentation time) and P9 (dose of inoculum $0.6 \%$ and 144 hours fermentation time). This research has been conducted since February 12 until March 3, 2017 at the Feed Technology Laboratory of the Faculty of Animal Husbandry of Sam Ratulangi University of Manado. The variables measured in this study are changes in ash content, crude fiber and crude fat. The result of variance analysis showed that the fermented banana peel with Rhizopus oligosporus gave significant different effect $(\mathrm{P}<0,05)$ to the change of ash content, crude fiber and crude fat. The treatment of inoculum dose $0.4 \%$ with fermentation time 96 hours has provided an increase in ash content $37.36 \%$, provided a decrease of crude fiber content $18.38 \%$ and provided decrease of crude fat content $17.33 \%$.Based on the results and discussion it can be concluded that bioconversion of banana peel (Musa Paradisiaca) with Rhizopus oligosporus can increase ash content, Reduce the content of crude fiber and crude fat.

Keywords: Banana peel, Bioconversion, Rhizopus oligosphorus.

\section{PENDAHULUAN}

Pakan merupakan faktor yang sangat penting dalam usaha peternakan. Keberhasilan suatu usaha peternakan banyak tergantung pada manajemen pakan. Kebutuhan pakan setiap ternak berbeda sesuai dengan jenis, umur, bobot badan, keadaan lingkungan dan kondisi fisiologi ternak. Pakan harus mengandung semua nutrien yang dibutuhkan oleh ternak namun tetap dalam jumlah yang seimbang. Nutrien yang dibutuhkan ternak antara lain protein, karbohidrat, lemak, vitamin, air dan mineral.

Pengeluaran terbanyak dalam suatu usaha peternakan adalah pakan. Sampai saat ini yang menjadi kendala bahan pakan adalah terbatasnya ketersediaan bahan baku penyusun ransum, sehingga pengadaan beberapa bahan baku pakan harus diimpor yang mengakibatkan harga bahan baku yang ada di pasar relatif tinggi dan jumlahnya terbatas. Salah satu cara yang bisa ditempuh dengan memanfaatkan sumber daya lokal yang melimpah, murah harganya, tidak bersaing dengan kebutuhan manusia, tersedia terus menerus dan mengandung zat-zat makanan yang dibutuhkan ternak. Limbah kulit pisang raja merupakan salah satu sumber daya lokal yang dapat di jadikan bahan pakan alternatif.

$$
\text { Kulit pisang raja (Musa }
$$

paradisiaca) adalah limbah hasil produk pangan yang tidak dimanfaatkan dan hanya dapat memberikan pengaruh buruk bagi lingkungan. Kulit pisang sangat potensial sebagai pakan karena ketersediaannya cukup banyak. Hasil analisis Laboratorium Ruminansia dan 
Kimia Pakan Unpad (2017) tepung kulit pisang raja (Musa paradisiaca) mengandung protein kasar $7.74 \%$, serat kasar $17.30 \%$, lemak kasar $3.02 \%$ dan abu $9.6 \%$.

Kulit pisang dapat dimanfaatkan sebagai bahan penyusun ransum namun terdapat beberapa kendala karena kandungan nutrien rendah. Oleh karena itu, perlu adanya upaya perbaikan kandungan nutrien diantaranya dengan proses fermentasi. Salah satu inokulum yang digunakan dalam proses fermentasi adalah jamur Rhizopus oligosporus. Udjianto et al., (2005) menyatakan bahwa kulit pisang yang difermentasi dengan prebiotik dapat meningkatkan kandungan protein kasar hingga $14.88 \%$ dan penurunan serat kasar hingga $11.43 \%$. Hasil penelitian Koni (2013) menyatakan bahwa kandungan serat kasar pada tepung kulit pisang kepok hasil fermentasi mengalami penurunan dari $18,71 \%$ sebelum fermentasi menjadi $15,75 \%$ setelah difermentasi. Fermentasi dapat meningkatkan kandungan protein kasar dan menurunkan kandungan serat kasar (Supriyati at al., 1998).

\section{MATERI DAN METODE PENELITIAN}

\section{Waktu dan Tempat Pelaksanaan}

Penelitian ini dilaksanakan di Laboratorium Teknologi dan Industri
Pakan Fakultas Peternakan Universitas Sam Ratulangi Manado. Penelitian ini berlangsung padatanggal 12 Februari sampai 3 Maret 2017.

\section{Alat dan Bahan Penelitian}

1. Kompor gas, kukusan, kantong plastik, baki plastik dan timbangan

2. Blender dan oven pengering

3. Kulit Pisang Raja diperoleh dari Limbah penggorengan pisang di Kota Manado

4. Ragi tempe (Rhizhopus oligosporus) diperoleh dari home industry tempe Manado

\section{Metode Penelitian}

\section{Pembuatan Inokulum Ragi Tempe (Rhizopus oligosporus)}

Sebanyak 320 gram ragi tempe diinokulasikan dengan 80 gram kulit pisang raja yang sudah dijadikan tepung, di simpan dalam toples yang sudah disterilkan supaya tidak terkontaminasi dengan mikroorganisme yang lain.

\section{Prosedur Fermentasi Kulit Pisang Raja (Musa paradisiaca)}

1. Kulit pisang yang telah dipilih, dicuci dengan air bersih, kemudian dipotong $\pm 2 \mathrm{~cm}$.

2. Kulit pisang yang telah dipotong dikukus menggunakan alat pengukus selama \pm 15 menit dihitung setelah air mendidih. Pengukusan berfungsi untuk mematikan pathogen pada kulit pisang.N Kulit pisang yang telah 
dikukus ditebarkan diatas nampan dan diangin-anginkan, setelah dingin dimasukan dalam kantong plastik.

3. Inokulasikan dengan inokulum yang telah yang telah dibuat sesuai dengan perlakuan yaitu $(0.2 \%, 0.4 \%$ dan 0.6 $\%$ ) dengan 400 gram kulit pisang raja.

4. Campur kulit pisang dengan inokulum sesuai dengan perlakuan sampai homogen, masing-masing dimasukan dalam kantong plastik yang sudah dilubangi ke 2 sisinya untuk mendapatkan kondisi aerob.

5. Inkubasikan dalam suhu ruang (25$28^{\circ} \mathrm{C}$ ) selama 48 jam , 96 jam dan 144 jam.

6. Setelah masing-masing waktu fermentasi dicapai, kulit pisang raja produk fermentasi dikeringkan dengan menggunakan oven pada suhu $60^{\circ} \mathrm{C}$ selama 3 hari (sampai diperoleh berat konstan).

7. Lakukan pengujian kandungan nutrisi produk fermentasi melalui analisis proksimat. (AOAC. 1995).

\section{Rancangan Percobaan}

Penelitian Fermentasi ini dilakukan secara Eksperimen di Laboratorium dengan mengunakan Rancangan Acak Lengkap (RAL) terdiri dari 9 perlakuan dan masing-masing perlakuan diulang 3 kali (Steel dan Torrie, 1995). Perlakuannya adalah Dosis Inokulum dan Waktu Fermentasi yaitu:
1. $\mathrm{P} 1=$ dosis inokulum 0.2 persen dan lama fermentasi 48 jam

2. $\mathrm{P} 2=$ dosis inokulum 0.4 persen dan lama fermentasi 48 jam

3. $\mathrm{P} 3=$ dosis inokulum 0.6 persen dan lama fermentasi 48 jam

4. $\mathrm{P} 4=$ dosis inokulum 0.2 persen dan lama fermentasi 96 jam

5. $\mathrm{P} 5=$ dosis inokulum 0.4 persen dan lama fermentasi 96 jam

6. $\mathrm{P} 6=$ dosis inokulum 0.6 persen dan lama fermentasi 96 jam

7. $\mathrm{P} 7=$ dosis inokulum 0.2 persen dan lama fermentasi 144 jam

8. $\mathrm{P} 8=$ dosis inokulum 0.4 persen dan lama fermentasi 144 jam

9. $\mathrm{P} 9=$ dosis inokulum 0.6 persen dan lama fermentasi 144 jam

Peubah yang diamati dan Cara Pengukurannya

Peubah yang diukur dalam penelitian ini adalah

1. Perubahan Kandungan Abu

2. Perubahan Kandungan Serat Kasar

3. Perubahan Kandungan Lemak Kasar

Perhitungan perubahan nilai komposisi mutrien yaitu :

$(\%)=\frac{\mathrm{K} 2-\mathrm{K} 1}{\mathrm{~K} 1} \times 100$

Keterangan:

$\mathrm{K} 1$ = Komponen nutrien (abu, serat kasar dan lemak kasar) Sebelum fermentasi $\mathrm{K} 2$ = Komponen nutrien (abu, serat kasar dan lemak kasar) Produk fermentasi 
HASIL DAN PEMBAHASAN

\section{Pengaruh Perlakuan Fermentasi Kulit Pisang Raja (Musa paradisiaca) dengan Rhizopus oligosphorus Terhadap Perubahan Kandungan Abu.}

Data hasil penelitian pengaruh perlakuan terhadap perubahan kandungan abu pada kulit pisang raja (Musa paradisiaca) dengan Rhizopus oligosphorus tercantum pada Tabel 1. Hasil penelitian menunjukkan bahwa persentase perubahan kandungan abu yang difermentasi bervariasi yaitu antara 8,20 $42.74 \%$. rataan persentase kandungan abu tertinggi pada perlakuan P8 yaitu dosis inokulum $0,4 \%$ dengan lama fermentasi 144 jam, sedangkan persentase perubahan kandungan abu terendah diperoleh dari perlakuan P1 yaitu dosis inokulum 0,2\% dengan waktu fermentasi 48 jam .Kandungan abu yang diperoleh dari hasil fermentasi menunjukkan bahwa perlakuan berpengaruh pada perubahan persentase kandungan abu.
Hasil penelitian menunjukkan adanya peningkatan persentase perubahan kandungan abu kulit pisang raja (Musa paradisiaca) difermentasi dengan Rhizopus oligosphorus di setiap perlakuan. Hasil analisis sidik ragam menunjukkan bahwa fermentasi kulit pisang raja (Musa paradisiaca) dengan Rhizopus oligosphorus memberikan pengaruh yang berbeda nyata $(\mathrm{P}<0,05)$ terhadap perubahan kandungan abu. Selanjutnya, untuk melihat perbedaan pengaruh antar perlakuan, dilakukan uji lanjut Beda Nyata Jujur (BNJ).Uji lanjut BNJ menunjukkan bahwa persentase kandungan abu pada perlakuan $\mathrm{P} 8$ berbeda tidak nyata $(\mathrm{P}>0,05)$ dengan perlakuan P9dan perlakuan P5 namun berbeda nyata $(\mathrm{P}<0,05)$ lebih tinggi dibandingkan dengan perlakuan P6, P7, P4, P2, P3 dan P1. Hal ini artinya semakin tinggi dosis inokulum dan semakin lama waktu fermentasi menyebabkan meningkatnya persentase perubahan kandungan

Tabel 1. Perubahan Kandungan Abu Kulit Pisang Raja (Musa paradisiaca) difermentasi dengan Rhizopus oligosphorus

\begin{tabular}{|c|c|c|c|c|c|}
\hline \multirow[t]{2}{*}{ Perlakuan } & \multicolumn{3}{|c|}{ Ulangan } & \multirow[t]{2}{*}{ Total } & \multirow[t]{2}{*}{ Rataan $(\%)$} \\
\hline & 1 & 2 & 3 & & \\
\hline P1 & 9,48 & 8,65 & 6,46 & 24,59 & $8,20^{\mathrm{d}}$ \\
\hline P2 & 9,58 & 13,54 & 14,69 & 37,81 & $12,61^{\mathrm{d}}$ \\
\hline P3 & 12,29 & 14,69 & 9,38 & 36,36 & $12,12^{\mathrm{d}}$ \\
\hline P4 & 20,31 & 13,44 & 14,79 & 48,54 & $16,18^{\mathrm{cd}}$ \\
\hline P5 & 40,10 & 34,38 & 37,60 & 112,08 & $37,36^{\mathrm{ab}}$ \\
\hline P6 & 27,50 & 33,33 & 23,96 & 84,79 & $28,26^{\mathrm{bc}}$ \\
\hline P7 & 10,00 & 22,50 & 23,02 & 55,52 & $18,51^{\mathrm{cd}}$ \\
\hline P8 & 48,33 & 45,63 & 34,27 & 128,23 & $42,74^{\mathrm{a}}$ \\
\hline P9 & 41,25 & 34,58 & 44,69 & 120,52 & $40,17^{\mathrm{a}}$ \\
\hline
\end{tabular}

Keterangan : Superskrip berbeda pada kolom yang sama menunjukkan perbedaan yang nyata $(P<0,05)$ 
Persentase perubahan kandungan abu kulit pisang raja (Musa paradisiaca) difermentasi dengan Rhizopus oligosporus disebabkan oleh perbedaan dosis inokulum dan waktu fermentasi. Wolayan (1998) menyatakan bahwa peningkatan kadar abu disebabkan adanya bahan kering yamg hilang selama proses fermentasi dan terbentuknya komponen baru, sehingga persentase pembentukan media awal berbeda dengan media setelah fermentasi. Kehilangan bahan kering akan meningkatkan konsentrasi bahan yang dapat diabukan dalam media. Menurut Yohanista et al.,(2014) bahwa kandungan abu hasil fermentasi menggunakan kapang Aspergillus niger atau kapang Rhizopus oligosporus maupun kapang kombinasi menunjukkan hasil yang sama yaitu semakin lama waktu inkubasi proses fermentasi maka akan meningkatkan kandungan abu pada substrat hasil fermentasi.Meningkatnya persentase perubahan kandungan abu pada penelitian ini disebabkan tingginya kandungan karbohidrat jenis selulosa yang dapat diubah menjadi asam organik dan terhidrolisis menjadi senyawa-senyawa lain, termasuk mineral yang dapat meningkatkan kadar abu (Affendi dan Yuniati, 2011), ini sejalan dengan pernyataan Nurhayati et al., (2006) yang melaporkan bahwa selama fermentasi terjadi peningkatan kandungan abu. Kenaikan kandungan abu masing-masing perlakuan disebabkan oleh berkembangnya biomasa kapang selama proses fermentasi dimana dinding selnya banyak mengandung silika (Sjofjan et al., 2001).

\section{Pengaruh Perlakuan Fermentasi Kulit Pisang Raja (Musa paradisiaca) dengan Rhizopus oligosphorus Terhadap Perubahan Kandungan Serat Kasar.}

Data hasil penelitian mengenai pengaruh perlakuan terhadap perubahan kandungan serat kasar pada kulit pisang difermentasi dengan Rhizopus oligosphorus tercantum pada Tabel 2.

Tabel 2. Perubahan Kandungan Serat Kasar Kulit Pisang Raja (Musa paradisiaca) difermentasi dengan Rhizopus oligosphorus

\begin{tabular}{cccccc}
\hline Perlakuan & \multicolumn{3}{c}{ Ulangan } & Total & Rataan $(\%)$ \\
\cline { 2 - 4 } & 1 & 2 & 3 & & \\
\hline P1 & 12,08 & 13,35 & 12,83 & 38,26 & $12,75^{\mathrm{e}}$ \\
P2 & 14,62 & 15,26 & 16,76 & 46,64 & $15,55^{\mathrm{c}}$ \\
P3 & $\mathbf{1 6 , 5 3}$ & $\mathbf{1 5 , 3 2}$ & $\mathbf{1 6 , 1 8}$ & $\mathbf{4 8 , 0 3}$ & $\mathbf{1 6 , 0 1}^{\mathbf{c}}$ \\
P4 & 15,14 & 13,12 & 14,68 & 42,94 & $14,31^{\mathrm{d}}$ \\
P5 & 17,75 & 18,32 & 19,08 & 55,15 & $18,38^{\mathrm{a}}$ \\
P6 & 16,94 & 17,17 & 18,96 & 53,07 & $17,69^{\mathrm{b}}$ \\
P7 & 15,95 & 14,05 & 16,59 & 46,59 & $15,53^{\mathrm{c}}$ \\
P8 & 17,80 & 18,55 & 15,26 & 51,61 & $17,20^{\mathrm{b}}$ \\
P9 & 18,96 & 19,08 & 17,86 & 55,90 & $18,63^{\mathrm{a}}$ \\
\hline
\end{tabular}

Keterangan : Superskrip berbeda pada kolom yang sama menunjukkan perbedaan yang nyata $(P<0,05)$ 
Rataan persentase perubahan kandungan serat kasar pada kulit pisang difermentasi dengan Rhizopus oligosporus pada penelitian ini yaitu $12,75-18,63 \%$. Persentase perubahan kandungan serat kasar kulit pisang raja tertinggi pada produk fermentasi P9 yaitu dosis inokulum 0,6\% dengan waktu fermentasi 144 jam dengan nilai persentase $18,63 \%$, sedangkan persentase perubahan kandungan serat kasar kulit pisang raja terendah pada produk fermentasi P1 yaitu dosis inokulum $0,2 \%$ dengan waktu fermentasi 48 jam dengan nilai persentase 12,75\%. Hal ini disebabkan karena semakin tinggi dosis inokulum dan semakin lama waktu fermentasi akan menyebabkan semakin rendah kandungan serat kasar pada kulit pisang raja (Musa Paradisiaca) difermentasi dengan Rhizopus oligosphorus. Menurut Rahmadi (2003) bahwa semakin lama waktu fermentasi menunjukkan turunnya kandungan serat kasar pada pakan yang difermentasi.

Hasil analisis sidik ragam menunjukkan bahwa kulit pisang raja (Musa paradisiaca) difermentasi dengan Rhizopus oligosphorus memberikan pengaruh yang berbeda nyata $(\mathrm{P}<0,05)$ terhadap perubahan kandungan serat kasar. Selanjutnya, untuk melihat perbedaan pengaruh antar perlakuan, dilakukan uji lanjut BNJ. Uji BNJ menunjukkan bahwa persentase kandungan serat kasar pada perlakuan P9 berbeda tidak nyata $(\mathrm{P}>0,05)$ dengan perlakuan P5 namun berbeda nyata $(\mathrm{P}<0,05)$ lebih besar di bandingkan dengan perlakuan P6, P8, P3, P2, P7, P4 dan P1. Menurut Lie at al., (2015) bahwa penurunan serat kasar terjadi seiiring dengan lamanya waktu fermentasi dan tingginya dosis inokulum,sejalan dengan pertumbuhan miselium yaitu pada saat bersamaan selulosa dan hemiselulosa mengalami degradasi.Persentase perubahan kandungan serat kasar antar perlakuan kulit pisang raja (Musa paradisiaca) difermentasi dengan Rhizopus oligosphorus disebabkan oleh perbedaan dosis inokulum dan waktu fermentasi. Pada perlakuan P2, P5 dan P8 memberikan perbedaan yang nyata $(\mathrm{P}<0,05)$ pada persentase perubahan kandungan serat kasar karenaRhizopus oligosporus mengalami perkembangan laju pertumbuhan dari fase adaptasi menuju fase eksponensial.

Fardiaz (1992) menjelaskan bahwa pola pertumbuhan mikroba adalah mulamula lambat (fase lag), karena usaha adaptasi dengan lingkungan, kemudian tumbuh cepat (fase log atau eksponensial) yaitu pada saat makanan berlimpah, kemudian akan melambat dan stasioner (fase stasioner), yaitu terjadi saat kondisi makanan dalam substrat menipis, kemudian pertumbuhan menurun dan 
menuju kematian (fase mati), yaitu terjadi jika zat nutrisi dalam substrat atau medium yang dibutuhkan mikroba sudah habis. Menurut Aang at al., (2012) bahwa peningkatan lama waktu fermentasi menyebabkan meningkatnya kesempatan mikroba untuk melakukan pertumbuhan dan fermentasi, sehingga semakin lama waktu fermentasi pada waktu tertentu, maka kesempatan mikroba untuk mendegradasi bahan yang difermentasi semakin tinggi.

Hasil uji lanjut beda nyata jujur (BNJ) menunjukkan terjadi perubahan persentase serat kasar yaitu semakin lama waktu fermentasi dan semakin tinggi dosis inokulum menunjukkan persentase penurunan serat kasar pada kulit pisang raja (Musa paradisiaca) difermentasi dengan Rhizopus oligosporus. Sukaryana et al., (2011) menyatakan bahwa fermentasi dapat meningkatkan kualitas bahan asalnya, seperti meningkatkan kandungan protein dan menurunkan kandungan serat kasar. Pernyataan ini didukung juga oleh Styawati et al., (2014) yang melaporkan bahwa kadar serat kasar menurun seiring dengan semakin meningkatnya lama waktu fermentasi. Selanjutnya Lie et al., (2015) menyatakan bahwa penurunan serat kasar dipengaruhi oleh dosis inokulum dan waktu fermentasi.
Pengaruh Perlakuan Fermentasi Kulit Pisang Raja (Musa paradisiaca) dengan Rhizopus oligosphorus Terhadap Perubahan Kandungan Lemak Kasar.

Data hasil penelitian mengenai pengaruh perlakuan terhadap perubahan kandungan lemak kasar pada kulit pisang difermentasi dengan Rhizopus oligosphorus tercantum pada Tabel 3.

Data hasil penelitian menunjukkan nilai persentase perubahan kandungan lemak kasar di setiap perlakuan bergantung pada dosis inokulum dan waktu fermentasi yang digunakan. Rataan kandungan lemak kasar pada kulit pisang difermentasi dengan rhizopus oligosporus pada penelitian ini yaitu $13,58-21,08 \%$. Persentase perubahan kandungan lemak kasar terendah dihasilkan oleh perlakuan P1 yaitu $13,58 \%$ sedangkan persentase perubahan kandungan lemak kasar tertinggi perlakuan P9 sebesar 21,08\%. Hal ini disebabkan karena semakin tinggi dosis inokulum dan semakin lama waktu fermentasi akan menyebabkan penurunan kandungan lemak kasar (Wolayan, 1998).

Data hasil penelitian mengenai pengaruh perlakuan terhadap perubahan kandungan lemak kasar pada kulit pisang difermentasi dengan Rhizopus oligosphorus tercantum pada Tabel 3. 
Tabel 3. Perubahan Kandungan Lemak Kasar Kulit Pisang Raja (Musa paradisiaca) difermentasi dengan Rhizopus oligosphorus

\begin{tabular}{cccccc}
\hline Perlakuan & \multicolumn{3}{c}{ Ulangan } & Total & Rataan $(\%)$ \\
\cline { 2 - 4 } & 1 & 2 & 3 & & \\
\hline P1 & 13,25 & 19,54 & 7,95 & 40,73 & $13,58^{\mathrm{d}}$ \\
P2 & 12,25 & 14,24 & 15,56 & 42,05 & $14,02^{\mathrm{d}}$ \\
P3 & 14,90 & 16,23 & 16,89 & 48,04 & $16,01^{\mathrm{bc}}$ \\
P4 & 15,89 & 14,24 & 13,91 & 44,04 & $14,68^{\mathrm{cd}}$ \\
P5 & 16,23 & 17,22 & 18,54 & 51,99 & $17,33^{\mathrm{bc}}$ \\
P6 & 17,88 & 19,54 & 17,22 & 54,64 & $18,21^{\mathrm{ab}}$ \\
P7 & 12,25 & 13,24 & 15,56 & 41,05 & $13,68^{\mathrm{d}}$ \\
P8 & 18,87 & 20,20 & 21,52 & 60,59 & $20,20^{\mathrm{a}}$ \\
P9 & 19,54 & 21,19 & 22,52 & 63,25 & $21,08^{\mathrm{a}}$ \\
\hline
\end{tabular}

Keterangan : Superskrip berbeda pada kolom yang sama menunjukkan perbedaan yang nyata $(P<0,05)$

Hasil analisis sidik ragam menunjukkan bahwa kulit pisang raja (Musa paradisiaca) difermentasi dengan Rhizopus oligosphorus memberikan pengaruh yang berbeda nyata $(\mathrm{P}<0,05)$. Selanjutnya, untuk melihat perbedaan pengaruh antar perlakuan, dilakukan Uji BNJ. Uji lanjut BNJmenunjukkan bahwa kandungan lemak kasar pada perlakuan P9 berbeda tidak nyata $(\mathrm{P}>0,05)$ dengan perlakuan P8 dan perlakuan P6 namun berbeda nyata $(\mathrm{P}<0,05)$ lebih besar dibandingkan dengan perlakuan P5, P3, P4, P2, P7 dan P1. Semakin lama waktu fermentasi memberikan pengaruh menurunnya kandungan lemak kasar. Menurut Ginting (2011) bahwa menurunnya kandungan lemak kasar seiring dengan lamanya waktu fermentasi dan tingginya dosis inokulum disebabkan karena aktivitas mikroba semakin aktif mendegradasi senyawa kompleks menjadi senyawa sederhana sehingga memudahkan degradasi lemak dari bahan yang difermentasi.

Peningkatan persentase perubahan kandungan lemak kasar kulit pisang raja (Musa paradisiaca) difermentasi dengan Rhizopus oligosphorus disebabkan oleh perbedaan dosis inokulum dan lama fermentasi. Hasil uji lanjut BNJ menunjukkan adanya kenaikan nilai persentase yaitu semakin lama waktu fermentasi dan semakin tinggi dosis inokulum pada kulit pisang raja (Musa paradisiaca) difermentasi dengan Rhizopus oligosporus menghasilkan persentase perubahan kandungan lemak kasar. Menurut Agustina et al (2015) bahwa semakin lama proses fermentasi berlangsung, semakin terjadi penurunan kandungan lemak kasar. Hal ini dikarenakan pertumbuhan mikroba yang terlalu cepat tidak diimbangi tersedianya nutrisi yang cukup. 


\section{KESIMPULAN}

Berdasarkan hasil dan pembahasan, maka dapat disimpulkan bahwa biokonversi kulit pisang raja (Musa paradisiaca) dengan Rhizopus oligosporus dapat meningkatkan kandungan abu, menurunkan kandungan serat kasar dan lemak kasar. Perlakuan pada dosis inokulum $0.4 \%$ dengan waktu fermentasi 96 memberikan peningkatan persentase perubahan kandungan abu sebesar $37,36 \%$, penurunan persentase perubahan kandungan serat kasar sebesar $18,38 \%$ dan penurunan persentase perubahan kandungan lemak kasar sebesar $17,33 \%$

\section{DAFTAR PUSTAKA}

Aang. R, Abun, dan A Tjitjah. 2012. Pengaruh Dosis dan Lama Fermentasi Buah Ketapang(Ficus lyrata) Oleh Bacillus licheniformis Terhadap Kandungan Protein Kasar dan Lemak Kasar. Fakultas Peternakan Universitas Padjadjaran.Jurnal Unpad 1 (1) :15

Agustina Y., Rudi. K dan Aman S P. 2015. Pengaruh Variasi Waktu Fermentasi Terhadap Kadar Laktosa, Lemak, Ph dan Keasaman Pada Susu Sapi Yang Difermentasi Menjadi Yogurt. Program Studi Kimia FMIPA Universitas Mulawarman. Jurnal Kimia Mulawarman Volume 12 (2) 97100.
Affendi dan Yuniati H. 2011. Pemanfaatan Limbah Ampas Kelapa Sawit Sebagai Substrat Untuk Sintesis Zat Gizi Melalui Fermentasi Kapang Rhizopus Oligosporus. EJournal. Litbang. 34(2):123-130

AOAC, 1995. Official Methods of Analysis of The Association of Analytical Chemists, Washington D.C.

Fardiaz, S. 1992. Mikrobiologi Pangan 1. Gramedia Pustaka Utama. Jakarta

Ginting. S. 2011. Pengaruh Lama Fermentasi dan Lama Penyangraian Biji Kakao Terhadap Mutu Bubuk Kakao. Program Studi Ilmu dan Teknologi Pangan. Fakultas Pertanian. Universitas Quality Medan. Jurnal Stevia 1 (1) :6-11

Koni. 2013. Pengaruh Pemanfaatan Kulit Pisang yang Difermentasi Terhadap Karkas Broiler. Jurnal Ilmu Ternak dan Veteriner 18 (2) : 153-157

Lie. M., M. Najoan dan F.R Wolayan.2015. Peningkatan Nilai Nutrien (Protein Kasar dan Serat Kasar) Limbah Solid Kelapa Sawit Terfermentasi dengan Trichoderma reesei. Pascasarjana Unsrat Manado. Jurnal LPPM Bidang Sains dan Teknologi. 2 (1) : 34-43

Nurhayati, O. Sjofjan dan Koentjoko. 2006. Kualitas nutrisi campuran bungkil inti sawit dan onggok yang difermentasi menggunakan Aspergillus niger. J. Indon. Trop. Anim. Agric. 31(3) : 172-178. 
Rahmadi, D. 2003. Pengaruh Lama Fermentasi dengan Kultur Mikroorganisme Campuran Terhadap Komposisi Kimia Limbah Kubis. Fakultas Peternakan Universitas Diponegoro, Semarang. J. Indon.Trop.Anim.Agric. 28(2) : 90-94.

Sjofjan, O., Aulanniam, D. Irfan., dan Surisdiarto. 2001. Perubahan Kandungan Bahan Organik dan Protein Pada Fermentasi Campuran Onggok dan Kotoran Ayam. Jurnal Ilmu-Ilmu Hayati 13 : 1-7

Steel, R. G. D dan J. H. Torrie. 1995. Prinsip Dan Prosedur Statistika. Penterjemah Bambang Sumantri. Gramedia Pustaka, Jakarta.

Styawati, Muhtarudin dan Liman. 2014. Pengaruh Lama Fermentasi Trametes sp. Terhadap Kadar Bahan Kering, Kadar Abu dan Kadar Serat Kasar Daun Nenas Varietas Smooth Cayene. Fakultas Pertanian UNILA. Jurnal Ilmiah Peternakan Terpadu .2 (1). 19-24

Sukaryana Y, U Atmomarsono., D.V Yunianto., E Supriyatna. 2011. Peningkatan Nilai Kecernaan Protein Kasar dan Lemak Kasar Produk Fermentasi Campuran Bungkil Inti Sawit dan Dedak Padi pada Broiler. Jurnal ITP. 1:167172.

Supriyati, T Pasaribu., H Hamid., A Sinurat. 1998. Fermentasi Bungkil Inti Sawit Secara Substrat Padat Dengan Menggunakan Aspergillus Niger. Jurnal Ilmu Ternak dan Veteriner 3(3):165-170

Udjianto A, E Rostiati dan D.R Purnama. 2005. Pengaruh Pemberian Limbah Kulit Pisang Fermentasi Terhadap Pertumbuhan Ayam Pedaging dan Analisa Usaha. Prosiding Temu Teknis Nasional Tenaga Fungsional Pertanian. Bogor 13-14 September $2005 . \quad$ Bogor (Indonesia): Pusat Penelitian dan Pengembangan Peternakan : 76-81.

Wolayan, F.R. 1998. Pengaruh Fermentasi Bungkil Kelapa Menggunakan Trichoderma viride terhadap Komposisi Kimia dan Kecernaan Protein pada Ayam Broiler. Tesis. Pascasarjana Universitas Padjadjaran Bandung.

Yohanista M., O. Sofjan dan E. Widodo. 2014. Evaluasi Nutrisi Campuran Onggok dan Ampas Tahu Terfermentasi Aspergillus niger, Rizhopus oligosporus dan Kombinasi Sebagai Bahan Pakan Pengganti Tepung Jagung. Fakultas Peternakan UB. Jurnal Ilmu-Ilmu Peternakan 24 (2): $72-83$ 
